\title{
From Situations of Dependency to Globalized Social Democracy
}

\author{
Peter Evans
}

Published online: 11 September 2009

(C) The Author(s) 2009. This article is published with open access at Springerlink.com

\begin{abstract}
President Cardoso's recent assessment of the prospects for "globalized social democracy" raises, once again, the question of what space for agency exists within the global political economy for actors in the South, which was central to the analysis Cardoso and Faletto presented in Dependency and Development 40 years ago. Dependency and Development's "historical-structural" approach balanced belief in the possibility of political agency with a keen appreciation of structural constraint. Cardoso's current exploration of global possibilities carries forward both tradition of the historical-structural method, arguing that social democracy is an option in the South and that the globalized social democrats in the South will play a growing role in shaping global political institutions. He does not explore the possibility that social democrats in the South may need to play a role in shaping global economic rules. This paper argues that reconstructing global market rules is crucial to the long-run success of "globalized social democracies" in the South and that such reconstruction, however difficult, lies within the realm of the historically viable.
\end{abstract}

Keywords Globalization · Social democracy · Dependency Political economy

How can we build on the insights of Dependency and Development in Latin America? Can the approach offered by Cardoso and Faletto 40 years ago still give us leverage in analyzing the comparative political economy of development? It should. Dependency and Development was an immediate classic four decades ago in the Global North as well as in Latin America. One of the definitions of classics is that their lessons endure.

In this case, one of the authors has provided his own assessment of what we should take away from Dependency and Development. In his article for this special issue, President Cardoso looks back and reflects on what has changed in the ensuing

[originally prepared for Conference on "International Inequality: Then and Now," Watson Institute, Brown University, April 2008]

P. Evans $(\bowtie)$

Department of Sociology, University of California, Berkeley, CA, USA

e-mail: pevans@berkeley.edu 
40 years. His view of our current world incorporates his experience as a national and international leader who helped shape change, as well as his continuing role as an intellectual who observes and analyzes the results.

Commenting on a classic and the reflections of its eminent author may be hubris, but it is worth the risk if it stimulates further debate on both Dependency and Development and Cardoso's current reflections. I will try to push the debate forward by focusing on President Cardoso's concept of "globalized social democracy."

Analyzing the space for agency within the global political economy was a pervasive general theme in Dependency and Development. President Cardoso's discussion of "globalized social democracy" brings this issue to the fore once more. The idea of globalized social democracy has no obvious antecedent in Dependency and Development, but exploring it offers an opportunity to underline the continuing relevance of Cardoso and Faletto's theoretical and methodological approach. Before turning to globalized social democracy, I will begin with a quick review of the general perspectives on agency in Dependency and Development and in President Cardoso's recent reflections.

\section{Political Agency and the "Historical-Structural" Approach}

Dependency and Development aggressively rejected the idea that national situations were "mechanically conditioned by external domination" (1979: 173). ${ }^{1}$ It offered both North Americans and Latin Americans a way of moving beyond earlier forms of "structural analysis," whether in the form of mechanical theories of imperialism or equally onedimensional theories of modernization. The book ends with a paean to "collective action guided by political wills that make work what is structurally barely possible" (1979: 176).

Insistence on agency was carefully balanced by an appreciation of structural constraint. While Cardoso and Faletto applauded making work "what is structurally barely possible," they insisted that effective action also requires recognizing what is not structurally possible. For Cardoso and Faletto, "the course of history depends on the daring of those who propose to act in terms of historically viable goals" (1979: 176). Being too timid to recognize that "barely structurally possible" strategies may be possible is one route to failure; being too stubborn to recognize that certain forms of change are not "historically viable" is the other.

This sophisticated rendition of the proposition that "people make history but not as they choose" is fundamental to Dependency and Development, both methodologically and politically. Methodologically, it grounded Cardoso and Faletto's strategy of focusing on national variations in "situations of dependency." Politically, it aligned them with what Albert Hirschman would later label "a bias for hope."

Romantically voluntaristic visions of transformative rupture and "structural pessimist"2 rejections of the possibility of progressive change were both rife when

\footnotetext{
${ }^{1}$ Page numbers for Dependency and Development refer to the 1979 English edition published by the University of California Press.

${ }^{2}$ By "structural pessimist," I mean a political vision which assumes that the prevailing global power relations cannot be changed by political agency, are vulnerable only to cataclysmic collapse induced by their own structural contradictions, and leave no room for progressive variation at the national level. See Evans (2008)) for a more extended discussion.
} 
Dependency and Development was written. Both stood in the way of historical structural analysis. The structural pessimists' privileging of external domination made the comparative analysis of concrete "political struggles of groups and classes" in the Global South seems like a fruitless exercise. What difference could national variations possibly make? Romantic voluntarism made such analysis seem superfluous. Whatever the constraints were they would soon be overthrown.

Transcending this sterile dichotomy was fundamental to Cardoso and Faletto's extraordinary success. Their perspective put comparative analysis of the concrete "networks of interests and coercions that bind some social groups to others, some classes to others" (1979: 173) at the center of the political and intellectual agenda. While they did not propose concrete strategies for change, their analysis provided a framework for assessing the potential efficacy of different courses of action.

Forty years later, Cardoso continues to carry forward both the methodological and the political tradition. He argues that structural factors "condition-but do not determine - the shape taken by economic and political processes" (2009: 315). Globalization notwithstanding, a "certain margin of autonomy" for political strategy continues to remain (2009: 315). ${ }^{3}$ As in Dependency and Development, he closes his argument by underlining that the future of developing countries will depend "mainly, on the capacity of local societies and their leaders to frame policies...that seize opportunities" (2009: 316).

Cardoso still insists that "people make history but not as they choose" is a fundamental axiom for the analysis of political and economic trajectories. His assessment of "historically viable goals" does, however, seems to have shifted. In 2008, he is more optimistic that the well-being of ordinary citizens can be improved within the matrix of a global capitalist economy. Consequently, he is more willing to take the current structure of global market rules as given.

In the preface to the English edition of Dependency and Development, Cardoso and Faletto were very explicit about the limits of capitalist development.

It is not realistic to imagine that capitalist development will solve basic problems for the majority of the population. In the end, what has to be discussed as an alternative is not the consolidation of the state and the fulfillment of "autonomous capitalism" but how to supersede them. The important question, then, is how to construct paths toward socialism (1979: xxiv). ${ }^{4}$

The centrality of the socialist alternative is underlined again in the postscript to the English edition where Cardoso and Faletto argue that the "effective battle" is between "technocratic elitism" and a vision that can succeed in "transforming the demand for a more developed economy and a more democratic society into a state that expresses the vitality of truly popular forces, capable of seeking socialist forms for the social organization of the future (1979: 216)."

\footnotetext{
$\overline{3}$ Page numbers are from the 9/29 version of "New Paths: Globalization in Historical Perspective" (with 14 point type).

${ }^{4}$ Or, "By development in this context, we mean 'capitalist development....'. So, we do not mean by the notion of 'development' the achievement of a more egalitarian or more just society. These are not consequences expected from capitalist development, especially in peripheral economies (1979: xxiii).”
} 
In 2008, Cardoso sees at least certain nations of Latin America as capable of "active policies geared to reducing poverty and enhancing social well-being (2009: 309)" even while operating within a generally capitalist framework, nationally and globally. He also argues that " $[\mathrm{t}]$ he challenge of poverty is permanently at the core of the global agenda" (2009: 302).

While Cardoso in 2008 assumes that market society is here to stay-both nationally and globally-he makes no such assumption with regard to the specific structures of political domination that currently preside over the global political economy. Conviction that space for agency has expanded in relation to the global political order complements Cardoso's greater optimism with regard to meeting the needs of ordinary citizens within a market society.

Dependency and Development did not explicitly reject the possibility that "collective action guided by political wills" might be efficacious beyond the national level, but left the possibility unanalyzed. Cardoso and Faletto did not sign on to the more ambitious "Third Worldist" agendas that assumed that rebellion in the Global South would change the world. They did not invoke the 1950s spirit of Bandung with its aspirations that the Global South might build collective global action on the foundations of decolonization. Nor did they anticipate the 1970s movement in search of a "New International Economic Order." In Dependency and Development, the national level is the site of potential agency; the global level is the source of structural constraint.

Cardoso in 2008 also emphasizes global economic constraint. Indeed, he sees a positive side to such constraints. He cites Romano Prodi's belief that taking Italy into the EU would have a salutary effect because it would "impose the discipline from the outside in" (2009: 313). Just as he sees more space for "well-being" enhancing strategies under a market economy at the national level, Cardoso in 2008 also sees more space at the global level for "forms of international integration that safeguard national interests and ensure better standards of living, even though the global economy is determinant" (2009: 301).

At the same time, Cardoso's 2008 vision sees global political structures as surprisingly fragile. First, he considers the contemporary international balance of power as indicating "the end of the possibility for Global Empire" (2009: 301). Second, he is convinced of the "fragility" of the central institutions of global economic governance - the International Monetary Fund (IMF) and the World Bank. For Cardoso, "they are clearly incapable of managing the dynamism of the global economy" (2009: 299). The failures of existing global governance create the need for a "new global pact." As the possibility of the old G7 nations dominating the construction of this new pact wanes, the "emerging nations of the Global South, most prominently but by no means exclusively, the BRIC countries,", will all count in the shaping of a new global order in the twenty-first century" (2009: 304).

Cardoso's vision goes beyond asserting that countries from the Global South will become players in the existing global system of political and economic domination. For him, in the expanded participation of the South holds the promise of helping

\footnotetext{
5 "There is no military might or moral convening power capable of upholding a world controlled neither by a single hyper-power nor by a coalition of a few superpowers" (2009: 302).

${ }^{6}$ Brazil, Russia, India, and China.
} 
make the twenty-first century international order "more interested in the cooperation among nations to overcome poverty, the energy imbalance, and environmental issues, and to reduce inequalities" (2009: 304). In short, Cardoso's version of the twenty-first century takes existing global markets as givens, but offers ample space for global political agency.

\section{Globalized Social Democracy}

Given a framework that emphasizes opportunities for increasing the well-being of ordinary citizens in the South within the framework of a market economy and combines this possibility with a vision of a global political order in flux and open to agentive action, it is hardly surprising that globalized social democracy comes to the fore as a central concept in Cardoso's 2008 analysis.

In 2008, as in Dependency and Development, the empirical analysis revolves around comparisons among the major countries in Latin America. Antecedent economic strengths and weaknesses, more or less adept political strategies, and the ability of classes and social groups to "establish more solid institutional norms" combine in different ways to create a continentally scaled "complex array of situations with different shapes and opportunities for integrating into the globalized world" (2009: 306).

The most promising form of integration is what Cardoso labels "globalized social democracy," an agenda followed by Brazil under his own Presidency and, with some variation, by the succeeding Worker's Party governments led by Lula (Luiz Inácio da Silva) since becoming president in January 2003. Cardoso provides a succinct definition of this model as "one that takes into account the power of markets, but counterbalances its abuses by controlling it whenever possible, and that develops social policies capable of fighting poverty and reducing inequality" (2009: 310).

To succeed, globalized social democracy must be able to "seize the opportunities made available by the global market," (2009: 310) intrepidly embracing the globalization of its productive system. But this is only one side of success. Social policies aimed at alleviating both poverty and inequality must be pursued with the same aggressiveness. Both general social provision, like programs aimed at insuring universal access to health care and education and policies that target at specific disprivileged groups, like land reform and direct cash transfers, must receive the same level of policy attention that is given to strategies aimed at achieving more favorable integration with the global economy.

To some, globalized social democracy might seem like a contradictory combination. Conventional wisdom in Latin America (and the USA) has associated aggressive efforts at enhancing local welfare with attempts to insulate the domestic economy from the vagaries of global markets. In fact, something very much like Cardoso's globalized social democracy has been a dominant strategy in Europe for at least a half century (see Cameron 1984; Katzenstein 1984; Rodrik 1997). Moreover, Sandbrook et al. (2007: chapters 7 and 8) have recently argued that the same logic applies to the Global South.

Like the politics of the "situations of dependency" discussed in Dependency and Development, the dynamics of globalized social democracy are driven by the "the actions of groups, classes, organizations and social movements" (1979: 174) in 
responding to historically given structural constraints. Cardoso notes that in order to succeed in the globalized social democratic project, national political leaders and the state apparatuses they command must "foster and accept cooperation from nongovernmental organizations, including groups from the middle classes and even private entrepreneurs who embed themselves into public policies" (2009: 312).

Just as Cardoso's vision of globalized social democracy is faithful to the analytical strategy of Dependency and Development, it carries forward the political spirit of the earlier work. Cardoso and Faletto formulated their perspective before Albert Hirschman formally set out his advocacy of "a bias for hope," but Hirschman's vision fits that of Dependency and Development, as they acknowledge in their preface to the English edition (1979: xi). ${ }^{7}$

Hirschman argued that it was essential to go beyond proposing "strictly incremental changes" but at the same time necessary to avoid proposals "so revolutionary or so utopian that they have no chance of whatever to be adopted in the absence of prior total political change" (1971: 29). Cardoso and Faletto's insistence that political determination, skill, and imagination could "make work what is structurally barely possible" was very consistent with Hirschman's pragmatic optimism.

Cardoso's current insistence that it is possible for countries in the Global South to pursue the goals of well-being and social protection traditionally associated with social democracy in the rich countries of the Global North is even more clearly in the Hirschmanian tradition of "a bias for hope." It implies impressive political agency in the face of daunting structural constraint.

When it comes to exercising agency in the global arena, however, Cardoso's position seems to depend on whether the object of agency is the political order or the economic one. Despite characterizing contemporary Latin American social democracy as "globalized," Cardoso does not raise the question of what kind of global economic rules globalized social democrats might need to allow their national economic agendas to succeed. His intriguing assertions with regard to the possibilities for political agency at the global level are not taken up again when he discusses the economic and welfare goals of globalized social democracy.

By introducing the concept of globalized social democracy, Cardoso sets up a challenge. If economic engagement with the global political economy is central to globalized social democracy as a developmental trajectory, then it is hard to believe that its success does not depend on what kinds of rules govern global markets. It is equally hard to believe that global rules constructed by capital in the North favor the constituencies of social democracy in the South. Together, these assumptions imply that the proponents of globalized social democracy must reshape global market rules if they are to succeed. Figuring out whether this is possible is the challenge posed by Cardoso's analysis.

\section{Extending the Analysis of Globalized Social Democracy}

In addressing this challenge, I argue first for the assumption that the success of social democratic strategies in the Global South depends, in the long run, on the ability of

\footnotetext{
$\overline{7}$ The preface was written in 1976 .
} 
social groups and political leaders interested in pursuing such strategies discovering ways to exercise agency with respect to rules that govern global markets. Then, I argue, based on the concrete experience of recent decades, that such exercise of agency lies within the realm of "historically viable" goals. Finally, I will set out the obvious political obstacles that make effective action by social democrats in the South vis-a-vis global economic governance "structurally barely possible." In short, reconstructing global market rules is exactly the sort of arena to which the historicalstructural perspective is most fruitfully applied: a case in which collective action and political will are essential and success must be won in the face of severe structural constraint, if it is to be won at all.

The argument for reconstructing global market rules will be developed in four interconnected arenas. Trade rules are an obvious case. "Investors rights," which are central to most "free trade" agreements, are a second. Global property rights rules, which impose politically protected monopoly rights over the most important form of contemporary assets, are even more important in the long run. Finally, the latest global financial crisis has underlined again the costs to the Global South of the inability of Northern dominated institutions to construct the kind of robust, stable financial markets that are necessary to promote development in the South.

Having made a case for why globalized social democracies need to reshape global markets in order to succeed, I turn, in the following section, to why such an effort might lie within the realm of "historically viable" options. My arguments for the political possibility of global agency begin by echoing the arguments at the beginning of Cardoso's essay. Existing global governance institutions are weak and vulnerable and need "buy-in" from the major countries of the Global South if they are to survive. As the world inexorably becomes more "multi-polar" and the relative weakness of the US economy becomes more apparent, opportunities for the South to exercise agency expand.

Unfortunately, focusing on the public face of global governance makes market rules appear more malleable than they are. Private actors, operating behind the façade of public institutions and arenas, construct most global market rules. The current financial crisis notwithstanding, these actors remain powerful and politically connected. Reconstructing global market rules to facilitate globalized social democracy in the South would challenge the vested interests of private capital, a much harder task than attacking enfeebled public institutions like the IMF or the World Bank. Facing this reality forces us to take the question of whether agency by the proponents of globalized social democracy with respect to global market rules is "historically viable" very seriously.

\section{Why Try to Reconstruct Global Markets?}

Must globalized social democracies in the South reconstruct the rules that govern global markets in order to be successful? Cardoso does not appear to think so, but there are strong arguments for taking action with regard to global economic rules. ${ }^{8}$

\footnotetext{
${ }^{8}$ Sandbrook et al. (2007) also analyze the possibilities of the success of social democracies on the periphery without raising the question of changing global market rules, but their cases are all small countries that have little choice but to live with existing global rules, unless larger social democracies in the south are willing to lead efforts at reconstruction.
} 
Modern economic theory recognizes markets as complex, socially embedded institutions whose outcomes are contingent on the institutional matrix in which they are embedded. Historically, the success of social democracy has always depended on reshaping market rules. In the contemporary world, this includes global markets as well as national ones. ${ }^{9}$

For social democracies, reconstruction of labor markets with the aim of protecting the dignity and well-being of workers is a foundational goal. Similar goals drive efforts to reconstruct markets involved in the provision of basic services like health and education, as well as markets for basic goods like food, transportation, and housing. More recently, curbing the potentially destructive externalities involved in the consumption of natural resources is an increasingly central goal. In short, constructing distinctively "social democratic markets" is the heart of social democratic politics.

As national borders become less effective at differentiating markets, the politics of market construction become increasingly global. Distinctive national markets are not just undermined by the economic porousness of borders. The heightened legitimacy of domestically intrusive global market rules turns distinctive national markets into endangered species in all but the most powerful countries (Wade 2003). As John Ruggie (1994) cogently observed more than a decade ago, global rules now impinge on what was once considered domestic policy to a far greater degree than they did during the original post-World War II efforts to "internationalize" economic growth.

The specific relationship between existing global market rules and social democratic goals in the Global South gives the case for reconstruction extra weight. Because global markets have been constructed over the course of the last 400 years by capital and the states in the North, the rules were not designed to be friendly to the Global South, or to social democratic agendas. Social democratic agendas need market rules that balance the needs of the less privileged social groups against those of capital. Even capital in the South suffers from market rules biased in favor of established monopolies in the North. Rich social democracies of the Global North may suffer from the bias in favor of capital, but poor social democracies in the Global South suffer from both the class bias and the regional bias. The current domestic intrusiveness of global economic regulations, especially in the South, magnifies the effects of biased global rules.

The hypocrisy of current trade rules illustrates the regional dimension of the bias in the governance of global markets. Differential enforcement of "free trade" corresponds to regional differences in export profiles and competitiveness. On the one hand, subsidies and barriers to market access are etched into the structure of global agricultural markets for products in which rich country producers have disadvantageous cost structures. On the other, efforts on the part of countries of the Global South to set rules that might enable them to gain economies of scale in key areas of manufacturing are condemned as economically irrational "protectionism."

\footnotetext{
${ }^{9}$ Special credit for establishing this perspective in the contemporary social sciences should go to Polanyi (2001[1944]) for arguing so forcefully that such a disembedded, self-regulating market would have catastrophic consequences were one to actually be instantiated and persist. See also Fligstein (2001) for a contemporary analysis of market construction.
} 
The costs to the Global South of biased definitions of "free trade" are substantial. ${ }^{10}$ Oxfam's (2002: 98) estimate is $\$ 100$ billion a year. William Cline (2004) estimates that 400 million people a year are in poverty in the Global South because of unfair trade rules imposed by the North.

Rules governing the treatment of capital are as central to most modern "trade agreements" as rules about flows of commodities. Modern "trade agreements" reconstruct the domestic markets of all countries involved by expanding the rights of investors, ${ }^{11}$ undercutting the ability of signatories to engage in the sort of regulation of the behavior of capital normally associated with social democracy. Here, again, there is also a regional bias. Despite the "globalization" of the biggest and most successful corporations in the Global South, ${ }^{12}$ the vast bulk of the world's capital and its owners are located in the rich countries of the North. The primary effect of turning "trade agreements" into vehicles for protecting the profits of investors is to shift returns to corporations based in the North.

Perhaps most fundamental to the construction of global markets are the rules that define property rights. Current controversies over "intellectual property rights" illustrate their importance. In the modern world, the most valuable and contentious form of property is the right to appropriate returns from ideas, information, images, and other intangible assets. Whereas maintaining "public order" is usually sufficient for the owners of physical assets to feel secure in their property rights, intangible assets require intensive, politically enforced protection. Such assets, such as computer software or the chemical formulas involved in the production of medications, are also key drivers of profits and growth. ${ }^{13}$ They are, as Weber and Bussell (2005) put it, the steam engines of the twenty-first century. The current property rights regime awards Northern corporations politically protected monopoly rights over these assets and attempts to enforce these rights around the globe (Evans 2005).

Since intangible assets are non-rival goods, which can be used simultaneously by any number of people around the globe, restricting their use by granting monopoly rights has powerful negative implications, especially in the Global South. Monopoly control of these "intangible steam engines" not only forces the South to pay costly "tribute" to Northern corporations but also robs global society of potential production, ${ }^{14}$ impedes innovation, ${ }^{15}$ and slows economic growth.

\footnotetext{
${ }^{10}$ This remains true despite the South's recent windfall gains from the "China effect" in global markets. See Castro $(2007,2008)$ on the benefits of the increasingly "Sino-centric" global economy.

${ }^{11}$ For an example of this process, see the examination of NAFTA and the proposed Free Trade Agreement of the Americas in Barenberg and Evans (2004)).

${ }^{12}$ See Cardoso 2008 footnote 6.

${ }^{13}$ Both the theoretical propositions of the "new growth" theory and econometric observations of differential returns in the latter half of the twentieth century point to the centrality of "intangible assets" in generating growth (see Aghion and Howitt 1998; Helpman 2004; Romer 1986, 1990).

${ }^{14}$ The case of open-source software (Weber 2003) offers a nice illustration of the productive dividends that non-exclusive property rights can deliver.

${ }^{15}$ Opponents of this position will argue that the incentive effects of expected monopoly returns increase the output of new ideas and outweigh the negative effects of subsequent restricted access. How the balance works out in practice depends on specific institutional contexts. In the case of medications, for example, the evidence would seem to support the negative consequences of enforcing monopoly rights. See Angell (2004) for a popular but well-argued exposition.
} 
The consequences of allowing monopoly protection of rights to intangible assets are especially negative for the Global South. Despite lower educational levels, the South has an abundance of underutilized "human capital."16 These skilled, potentially productive individuals, lacking the access to productive capital that a less exclusionary property rights regime would afford them, suffer from the twentyfirst century equivalent of the deprivation suffered in an earlier era by peasants whose access to land is rationed to preserve the power of landlords. To realize the productive potential currently kept idle, social democrats in the Global South must contest current property rights rules at the global level.

If the global rules and institutions that defend intellectual property rights are excessively muscular from the point of the Global South, the rules and institutions that govern financial markets are excessively weak. In finance, private actors, who weigh profit maximization far more heavily than stability and risk prevention, have dominated market construction. The public rules and institutions that should increase stability and alleviate risks are too weak to counter private bias. They lack the capacity to enforce even the market rules that the private sector needs.

Once again, the costs of constructing markets to maximize the returns to vested economic interests are borne disproportionately by the Global South. As Guillermo Perry (2008) of the Center for Global Development recently pointed out, "financial shocks are more frequent and costly in developing countries than in the developed world, and their welfare costs are higher both in the short and long term." The countries of the Global South have been forced to lock up savings in foreign exchange reserves that, in a less financially volatile world, could be invested to meet the needs of their real economies. At the same time, high interest rates designed to attract funds from foreign lenders reduce the range of new local investments that can be considered economically viable. And, as the current financial crisis indicates, even massive foreign reserves and high interest rates are insufficient to avoid attacks on the currencies of the Global South.

The current construction of global financial markets clearly impedes social democratic projects in the Global South. Yet, in the case of global financial markets, the challenge facing social democrats in the South is less contestational than in areas like property rights. State managers in the North and far-sighted global capitalists would agree that more robust and enforceable rules are desirable despite their failure to implement such rules. The challenge is mustering the political will to construct better rules and build stronger institutions to enforce them.

Newly intrusive global rules stymie domestic efforts to introduce social protection into labor markets and to expand the access of ordinary citizens to the productive assets they need to become more productive. Biases toward Northern capital and inadequate attention to stability and avoiding unnecessary shocks further prejudice social democratic efforts to provide security and social protection. A playing field that is already "tilted" against the social democratic agenda by the power of capital in national political arenas is further tilted by global market rules.

\footnotetext{
${ }^{16}$ The contradiction between property rights over intangible assets and development is not novel. As HaJoon Chang (2002) emphasizes, the historical response of governments in the North to the negative developmental consequences of granting exclusive property rights over ideas was essentially to ignore the property rights of foreign corporations.
} 


\section{Contemporary Efforts to Exercise Global Agency}

Acknowledging that the long-run success of globalized social democracy depends on reconstructing global markets shifts the focus to political feasibility. If the reconstruction of global markets were clearly outside the bounds of the "historically viable," then focusing on global rules would only reinforce the "structural pessimism" that Cardoso and Faletto were trying to escape. Fortunately, recent experience suggests otherwise. Possibilities for global agency have been demonstrated. They may even be expanding.

Seeing the South as an agent of global change is consistent with Cardoso's 2008 vision. He is unambiguous in his conviction that the South is going to "count in the shaping of a new global order in the twenty-first century" (2009: 304). What he does not address is whether the South can "count" in relation to the reconstruction of global markets. When it comes to global economic rules, Cardoso appears to be more convinced of the necessity of accepting the "discipline" imposed by existing market rules. ${ }^{17}$ Accepting discipline and trying to discover competitive space within the existing structure of the global political economy is, indeed, the predominant mode of the South's relation to global markets. Nonetheless, recent decades have seen numerous examples of contestation as well, including a number involving Brazil. Looking at these examples is a good way to start thinking about the potential space for agency.

Efforts to reconstruct global markets have taken a variety of forms. First, there are "within the system" initiatives to force the North to conform to its own rules. The World Trade Organization (WTO) has been a prime site for this sort of action. Such challenges have the advantage of low collective action requirements. While several countries may join together, failure to do so is not a barrier to action. Individual countries can take the initiative. In addition, this kind of action usually benefits from the unambiguous support of national economic elites.

Collective, multi-country efforts to shape new rules are more difficult but more important. These can have negative agendas, as in fights against the imposition of new regional "free trade" agreements. Or they can be a mixture of negative and positive agendas as in the Global South's collective refusal to go along new sets of trade rules in Seattle, Cancun, and Doha. Such contestation does not question the basic structure of existing markets, but demands more consistency and less bias. They are essentially more collective versions of the contestation of individual cases in the WTO.

Other efforts to shift accepted modes of implementing existing market rules are more ambitious. Current struggles over how "intellectual property rights" should be defined and exercised offer nice examples. Finally, there are efforts to reconstruct the rules of global financial markets. These are the least developed of all, but the current global financial crisis may have created new opportunities for the Global South in this arena. Brazil's own actions vis-a-vis global market rules over the course of the past two decades provide some of the best illustrations of different modes of contestation. I will offer brief comments on few of them as illustrations.

To begin with, Brazil has been active within the WTO, successfully contesting "rigged rules and double standards" on an individual basis and jointly with other

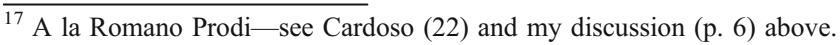


countries. Brazil has also been a player in most of the collective efforts to force the North to accept less biased global trade rules, from Seattle through the Doha round. Brazil has also contested property rights. Its fight against the politically enforced monopoly rents enjoyed by "Big Pharma" is a specific example. Its efforts to build a "Development Friendly Agenda" for reconstructing intellectual property rights at the World Intellectual Property Rights Organization (WIPO) exemplify a general, collective effort at reconstructing property rights. ${ }^{18}$

Removing the ability of powerful actors to enjoy particularistic exceptions to general rules is the easiest form market reconstruction. Brazil's successful actions in the WTO during both Cardoso and Lula administrations are good illustrative cases. With a consistency that may seem surprising, Brazil succeeded in winning dispute settlement cases against G7 countries forcing the North to withdraw subsidies and special tariffs across a range of different product arenas from cotton to sugar to steel to jet aircraft. Each case was different, but in each case, the fact that WTO moved market competition from being embedded in informal power relations to being the object of transparent, formal contestation worked to Brazil's advantage. I focus on two cases: aircraft and cotton.

The fight between Brazil's Embraer and Canada's Bombardier, which began during President Cardoso's administration, shows how important contesting de facto market rules can be to efforts to build high value-added production in the Global South. Both the Canadian and Brazilian governments were trying to sustain niches in the lucrative and expending market for short to mid-range jet passenger planes. Both were willing to do whatever was necessary to support their firms but needed the legitimacy of conformity to global rules. Each accused the other of offering illegitimate subsidies in filings to the WTO each. In the end, Brazil succeeded not only in fending off the Canadian threat and forcing the Canadian government to modify its support for Bombardier. A few years later, Embraer was in the running for a contract to sell its planes to Air Canada. ${ }^{19}$

Had Brazil neglected to contest the way market rules were applied at the global level, one of its signature hi-tech producers could have been driven out of a key market with important technological spillovers. The Embraer case underlines, first of all, that vigilance with respect to global rules must be an integral part strategies of domestic accumulation. It also shows that despite the obvious Northern bias in the politics, structure, and ideological assumptions of the WTO (see Chorev 2005), it is still a venue in which southern social democrats can exercise agency. Brazil is not the only country in the Global South to have figured this out. In the period from 2000 to 2004, WTO dispute settlement panels initiated by developing countries against developed ones were more than three times more likely than cases initiated by developed against developing countries. ${ }^{20}$

Brazil's WTO case against US cotton subsidies fits standard expectations more closely: a country in the Global South contesting Northern protection of agricultural

\footnotetext{
${ }^{18}$ Other sorts of cases could be added-for example, Brazil's contribution to derailing the free trade agreement of the Americas (FTAA/ALCA) or its efforts to promote open-source software.

${ }^{19}$ See Schrank and Kurtz (2005) for a discussion of the dispute with Bombardier and Embraer's subsequent economic successes.

${ }^{20}$ For data on WTO dispute settlement cases, see http://www.worldtradelaw.net/.
} 
producers. For precisely that reason, the case had broader implications for collective action. Brazil argued that US subsidies to its domestic cotton producers were illegitimate. The WTO dispute settlement panel concurred in 2004. ${ }^{21}$ Brazil's success helped embolden the poor West African Countries of Benin, Chad, Mali, and Burkina Faso for whom cotton exports are a crucial economic issue. They in turn have made more full-fledged reductions in US cotton subsidies a central issue in the prospective Doha round negotiations on agricultural subsidies.

If we turn from trade to contestation over prevailing definitions of intellectual property rights, Brazil's role has been even more prominent. Two examples will be developed here: (1) the specific case of redefining property rights with respect to pharmaceuticals (most crucially anti-retroviral drugs) and (2) participation in the general efforts to write more "development friendly" intellectual property rights rules at WIPO.

Success in treating and preventing AIDS has been one of the most impressive achievements of Brazil's globalized social democracy. Domestic politics were the cornerstone of this accomplishment, but contesting global market rules and property rights also played a central role. As the Brazilian government's fiscal commitments to provide anti-retroviral drugs (ARVs) to AIDS victims began to grow, it was clear to José Serra (Cardoso's Minister of Health) that the obscene ratios between the prices charged for these drugs and their actual costs of production were a threat to Brazil's fight against AIDS (Shadlen 2008).

What followed from the 1990s to the present has been a complex political-legal ballet in which Brazil both pressured globally for the right of poor countries to use generic AIDS drugs and reconstructed its national patent laws to facilitate its ability to use the space that existed within the global "TRIPS" regime. Brazil's principle tool in its fight with Big Pharma was the threat of "compulsory licensing," which allowed Brazil (within the TRIPS regime) to issue a license for local firms to produce ARVs that were patented by Big Pharma firms on grounds of overriding public interest. In 2001, Brazil's threat to license one of Roche's patented ARVs was sufficiently credible to extract a price reduction. Subsequently, the same tactics were used against Abbott and Merck. In 2007, Brazil actually carried through with its threat and issued a compulsory license to produce one of Merck's ARVs (Shadlen 2007: 567).

Brazil's successful contestation of pharmaceutical patents demonstrated the potential effectiveness of taking action against regressive global property rules. It did not, however, change the rules themselves. It only expanded the possibilities for how they might be implemented at the national level. Brazil's efforts (working together with Argentina and the other members of the "Group of Friends of Development") on behalf of the "Development Friendly Agenda" at WIPO have been aimed at changing the rules themselves, opening up possibilities that would also benefit countries more vulnerable and less willing to push the possibilities of existing rules than Brazil itself.

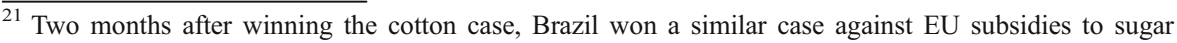
producers. A year earlier, it had won a case against US steel subsidies.
} 
Shifting the global property rights agenda away from more draconian enforcement of existing rights in the direction of what is delicately called more "development friendly" modes of property rights is a monumental task (Musungu 2007). The efforts of the "Group of Friends" have been painfully diplomatic. For example, their opening proposal says cautiously:

Intellectual property protection cannot be seen as an end in itself, nor can the harmonization of intellectual property laws leading to higher protection standards in all countries, irrespective of their levels of development. The role of intellectual property and its impact on development must be carefully assessed on a case-by-case basis (WIPO 2004).

It is hard to imagine a less threatening statement of the issues. Yet, in the context of powerful and deeply entrenched privilege, setting out this mild-mannered declaration at WIPO was like nailing theses to the door of the church.

The response of the pharmaceutical industry and other sectors that benefit from the current property rights regime to the proposals put forward by Brazil and its allies at WIPO is indicative of the uncompromising resistance that any such change will face. In addition to marshalling their political and organization resources within WIPO, the industry opened a second front in the form of the "Anti-Counterfeiting Trade Agreement" (ACTA) launched through a more dependable public organization - the US Special Trade Representative (see Shaw 2008; Sell 2008).

Under the apparently neutral rubric of "anti-counterfeiting," ACTA would move intellectual property rights firmly back in the direction of draconian enforcement. It was proposed as a "plurilateral" treaty, which is to say that it could be advanced initially by a small group of states from the North (led by the USA). The strategy was aimed at bypassing the Global South in the construction of a new set of property rights rules that could be imposed on any country that wanted to trade with the signatories. On the one hand, this response to Brazil's engagement on behalf of more "development friendly" property rights is an indication of just how difficult it is to reconstruct global markets. Yet, the fact that Northern corporate interests no longer felt secure in relying on traditional global governance venues like WIPO to defend their interests must be considered a significant retreat in the face of the South's new efforts.

The obduracy with which Northern capital defends its property rights in the face of initiatives in the South stands in revealing contrast to current efforts on the part of Northern governments to increase the engagement of the South in the revitalization of global governance institutions in the area of finance. The financial arena poses the question of global agency in a very different way. The hypothetical future is more interesting than past fights.

The recent Commonwealth initiative in favor of a "New Bretton Woods" offers a nice illustration of how the recent financial crisis has focused attention on the fragility of existing global financial governance and expanded the political space for the participation of the Global South (Woods 2008). It also makes clear how hard it is for collective efforts to reconstruct global financial governance to get beyond the most marginal and superficial changes. 
After lamenting the institutional "crises" confronting both the IMF and the World Bank, ${ }^{22}$ the report goes on to underline that the anachronistic nature of governance structures that give veto power to the $\mathrm{USA}^{23}$ focuses heavily on the importance of getting increased "buy-in" from the major countries of the Global South, recognizing that countries like Brazil "have little incentive to push for reform within formal structures which are tilted against them" (Woods 2008: 2). While such openness to an expanded role for the Global South in reconstructing global financial governance is hardly pervasive among politicians and state managers in the North (say nothing of the board rooms of private financial corporations), it still indicates that the exercise of agency by countries of the South in the structuring of global market rules is no longer considered a fanciful proposition, even in the North.

Across a range of global economic arenas, the Global South's efforts to reconstruct market rules are on-going, sometimes meeting intransigence, as in the case of intellectual property rights, occasionally encouraged as in the recent efforts to restructure the governance of global financial markets.

\section{Is Global Agency "Historically Viable"?}

Skeptics will not be impressed by the examples I have offered. They will argue that only the most marginal changes have been achieved and that significant reconstruction of global market rules is not a "historically viable" agenda. They are right to be skeptical. Even though examples of efforts by the South to shift global market rules are not hard to find, the exercise of global agency still remains in the realm of the "structurally barely possible." Panglossian assessments of the ease of changing global market rules would be a disservice both to political leaders in the Global South who are trying to effect change and to ordinary people who need new rules if they are to look forward to enjoying the benefits of "globalized social democracy."

Two kinds of barriers stand in the way of the construction of global market rules more supportive of social democratic projects in the South. The obvious impediment is opposition from vested interests in the North. Even when the goal is forcing Northern states to conform to their own definitions of markets as "level playing fields," the ability of vested interests to block change seems disproportionate to their real economic and political power. Challenging the North's definition of what constitutes a level playing field produces a more aggressive response. Defenders of the "intellectual property rights" status quo may make strategic concessions, as in the

\footnotetext{
${ }^{22}$ The commonwealth report notes (Woods 2008: 1) that the income of the IMF has "plummeted" to the point that it faces a $\$ 400$ million shortfall in 2010 and that while for the World Bank "the crisis is less imminent," the "pressures are building." Cardoso (5) agrees but is less charitable not just noting the "fragility" of these institutions but adding that they are "clearly incapable" of making an effective contribution to the governance of the contemporary global economy.

${ }^{23}$ The report does not mince words with regard to the changed position of the USA, stating directly, "Governance in the IMF reflects a world in which the US was the largest creditor and financial stability depended upon decisions made in the USA or G7. Today, the USA is the world's largest debtor and financial stability depends as much on decisions being made in Beijing and Dubai” (Woods 2008: 2).
} 
case of AIDS drugs, but they apply their almost inexhaustible resources with ferocity and determination in defense of the general framework of monopoly protection.

Global financial governance illustrates a conceptually different, but equally imposing, kind of obstacle to the exercise of agency at the global level. Northern elites have a massive "collective action problem." They are incapable of securing even reconstructions that are in their own immediate interests. Even if they were completely supportive of South-initiated social democratic restructuring, they are bereft of the "infrastructural power" (Mann 1994) that would enable them to implement the project.

Entrenched private resistance and public incapacity is a formidable combination. Global economic power is largely private, obdurate, and unaccountable. Public power is more vulnerable to contestation, but resides in a politically fractured global political structure, crippled with respect to their capacity for constructive collective action.

The collective action problems faced by the "globalized social democrats" themselves create additional obstacles. The simplified language in which the nations of the "South" confront the "North" must be complicated in order to become realistic. Conceptualizing the "South" as a homogenous block of nations with fully overlapping shared interests violates empirical reality. Instead, any consideration of efforts to restructure global markets must deal, first of all, with the immense and rapidly increasing heterogeneity of the "South." The current national agendas of China and Haiti have little in common, and it is unclear whether Korea should be located in the North or the South.

This is not to deny the existence of a set of interests that transcend the heterogeneity. The historical hegemony of the North created shared interests in the South that persist. Private property rights, particularly rights with regard to intangible assets, remain concentrated in the North while poverty is overwhelmingly concentrated in the South. The problem is that the operational content of shared interests must be continuously defined and redefined through political interchange. Then, even if shared interests can be identified, poor countries must be convinced to give them priority over short-term deals that speak directly to their individual national interests.

What is surprising is that the countries of the South have been able to engage in collective action at all. Building from a blocking coalition in Seattle to one with a positive agenda in Cancun, forming the original "Group of 20" and avoiding fragmentation and capitulation in the Doha round has been an impressive sequence of successful collective action. Analysis of how this capacity for collective action among the nations of the Global South emerged and has been sustained is one key to understanding the potential for global agency.

Trying to achieve a social democratic agenda in relation to the reconstruction of global markets also creates collective action problems at the national level. The assumption that "nations" have unitary interests with respect to global economic issues is as unsustainable today as it was in the days of traditional, export-dependent landholders, "comprador" bourgeoisies, and settler elites. As Cardoso points out (footnote 6), the most successful local corporations in the South have redefined their interests in global terms. Even firms unable to become global actors themselves are increasingly enmeshed in transnational networks. Exploration of the future of globalized social democracy must include an assessment of the possibilities for 
transcending increasingly divergent interests at the national level, then consider how the resulting compromises might be aggregated to enable collective action internationally.

How can we go about analyzing such a bewildering multilevel combination of partially shared interests and complex alliances? Cardoso and Faletto's "historicalstructural" method continues to offer an apt methodological model. While it has been generally used for analyses of national "situations of dependency" that take the politics of the global arena as essentially exogenous, there is no reason why Cardoso and Faletto's methodology cannot be extended to political dynamics that include political action at the global level.

What better strategy for analyzing the complexities of global political action than starting with a respectful acknowledgement of the power of structural determination, then adding a careful analysis of the "networks of interest" that "bind some social groups to others" (Cardoso and Faletto 1979: 173) along with analysis of conflicts among classes and social groups and between these and the state (Cardoso and Faletto 1979: 174), considered with an appreciation for the political dynamics created by contradictions between national agendas and those imposed by the global political economy (Cardoso and Faletto 1979: 174)? Just as it makes sense to extend the substantive analysis of "globalized social democracy" to the global arena, it makes sense to extend Cardoso and Faletto's methodological approach.

Just as Cardoso and Faletto's analysis of national situations of dependency made no claim to predict an obvious logic of national transformation, the "historical structural" method is unlikely to produce a prognostication of easy agency in contemporary global arenas. Nonetheless, looking at current global politics through the lens of the historical structural method still offers the best analytical foundation for debates on political strategy.

\section{Globalizing the Bias for Hope}

Reconstructing global markets to create a world friendlier to "globalized social democracy" is a project at the boundary the "historically viable." At the same time, accepting the current institutionalization of global markets as given is not a practical option for social democrats in the South. Even the most pragmatic globalized social democrats have found it impossible to avoid challenging global rules. Brazil is unlikely to abandon its aggressive activism in the WTO or its carefully incremental challenges in WIPO. It is also unlikely to withdraw from collective efforts to challenge global trading rules. The same is true of other major countries of the Global South. As long as this is the case, the search for effective global strategies makes sense. Leaving the construction of global markets to the corporate North risks the sustainability of policy successes at the national level in the South.

In the century just past, consolidating the original achievement of social democratic gains in the North depended on winning difficult domestic battles, but it also depended on the post-World War II restructuring of global market rules. Currently, global market rules impede social democratic agendas in the South. Friendlier global market rules would significantly facilitate social democratic agendas at the domestic level. 
Failing to give serious consideration to the possibility of agency at the global level would be inconsistent with Hirschman's "bias for hope" and the political epistemology of Dependency and Development. Were Hirschman involved in the current "Bretton Woods II" initiative, he would undoubtedly be crafting proposals that have "concrete institutional detail, thereby deliberately creating the optical illusion that they could possibly be adopted tomorrow by men of good will"(Hirschman 1971: 29). Likewise, it is in the arena of global political action that we most need to remember Cardoso and Faletto's admonition that future events will depend on "collective action guided by political wills that make work what is structurally barely possible."

Open Access This article is distributed under the terms of the Creative Commons Attribution Noncommercial License which permits any noncommercial use, distribution, and reproduction in any medium, provided the original author(s) and source are credited.

\section{References}

Aghion P, Howitt P. Endogenous growth theory. Cambridge: MIT Press; 1998.

Angell M. The truth about drug companies: how they deceive us and what to do about it. New York: Random House; 2004.

Barenberg M, Evans P. The FTAA's impact on democratic governance. In: Estevadeordal A, Rodrik D, Taylor AM, Velasco A, editors. Integrating the Americas: FTAA and beyond. Cambridge, MA: Harvard University Press; 2004. p. 755-89.

Cameron DR. Social democracy, corporatism, labour quiesence and the representation of economic interest in advanced capitalist society. In: Goldthorpe JH, editor. Order and conflict in contemporary capitalism. Oxford: Oxford University Press; 1984. p. 143-78.

Cardoso FH. New Paths: Globalization in Historical Perspective. St Comp Int Dev. 2009;44(4):296-317. doi:10.1007/s12116-009-9050-3.

Cardoso FH, Faletto E. Dependency and development in Latin America. Berkeley: University of California Press; 1979.

Castro AB. "No espelho da China" Rio de Janeiro: Universidade Federal do Rio de Janeiro. Unpublished manuscript; 2007.

Castro AB. From semi-stagnation to growth in a Sino-centric market. Braz J Polit Econ [Revista de Economia Politica]. 2008;28(1):3-27.

Chang HJ. Kicking away the ladder: development strategy in historical perspective. London: Anthem; 2002.

Chorev N. The institutional project of neo-liberal globalism: the case of the WTO. Theory Soc. 2005;34:317-55.

Cline W. Trade policy and global poverty. Washington: Center for Global Development and Institute for International Economics; 2004.

Evans P. The new commons vs. the second enclosure movement: comments on an emerging agenda for development research. Stud Comp Int Dev. 2005;40(2):85-94.

Evans P. Is an alternative globalization possible? Polit Soc. 2008;36(2):271-305.

Fligstein N. The architecture of markets: an economic sociology of capitalist societies. Princeton: Princeton University Press; 2001.

Helpman E. The mystery of economic growth. Cambridge: Harvard University Press; 2004.

Hirschman A. A bias for hope. New Haven: Yale University Press; 1971.

Katzenstein P. Corporatism and change: Austria, Switzerland and the politics of industry. Ithaca: Cornell University Press; 1984.

Mann M. The sources of social power. New York: Cambridge University Press; 1994.

Musungu S. Rethinking innovation, development and intellectual property in the UN: WIPO and beyond. TRIPS Issues Paper no. 5. Quaker International Affairs Programme, Ottawa, Canada; 2007.

Oxfam International. Rigged rules and double-standards: trade, globalization and the fight against poverty. Oxford: Oxfam International; 2002. 
Perry G. Helping reduce volatility: the role of financial innovations in multilateral development banks. Washington: Center for Global Development; 2008.

Polanyi, Karl. The great transformation: the political and economic origins of our time. Boston: Beacon; 2001 [1944]

Rodrik D. Has globalization gone too far?. Washington: Institute for International Economics; 1997.

Romer P. Increasing returns and long-run growth. J Polit Econ. 1986;94:1002-37.

Romer P. Endogenous technological change. J Polit Econ. 1990;98:S71-102.

Ruggie J. At home abroad, abroad at home: international stability in the new world economy. Millennium: J Int Stud. 1994;24(3):507-26.

Sandbrook R, Heller P, Edelman M, Teichman J. Social democracy in the global periphery: origins, challenges and prospects. Cambridge: Cambridge University Press; 2007.

Schrank A, Kurtz MJ. Credit where credit is due: export diversification in Latin America and the Caribbean. Polit Soc. 2005;33(4):671-702.

Sell SK. The global IP upward ratchet, anti-counterfeiting and piracy enforcement efforts: the state of play. Washington: Institute for Global and International Studies, George Washington University; 2008.

Shadlen K. The political economy of AIDS treatment: intellectual property and the transformation of generic supply. Int Stud Q. 2007;51:559-81.

Shadlen K. The politics of patents and drugs in Brazil and Mexico: the industrial bases of health activism. Development Studies Institute (DESTIN), LSE. Unpublished manuscript; 2008.

Shaw A. The problem with the anti-counterfeiting trade agreement. Unpublished manuscript, Cambridge, MA; 2008.

Wade R. What strategies are viable for developing countries today? The World Trade Organization and the shrinking of 'development space'. Rev Int Polit Econ. 2003;104:621-44.

Weber S. The success of open source. Cambridge: Harvard University Press; 2003.

Weber S, Bussell J. Will information technology reshape the North-South asymmetry of power in the global political economy? Stud Comp Int Dev. 2005;40:62-84.

WIPO. Proposal by Argentina and Brazil for the establishment of a development agenda for WIPO. [WO/ GA/31/11], Geneva, Switzerland; 2004.

Woods N. (for the Commonwealth Secretariat). A commonwealth initiative to support reform of the IMF and the World Bank. Commonwealth Secretariat, London. Presented at Commonwealth Heads of Government Meeting on Reform of International Institutions [HGM-RII(08)3], 9-10 June; 2008.

Peter Evans is Professor of Sociology and Marjorie Meyer Eliaser Professor of International Studies at the University of California, Berkeley. His work on the comparative political economy of national development is exemplified by his 1995 book Embedded Autonomy: States and Industrial Transformation. He is now working on "counter-hegemonic globalization" with a focus on the role of the global labor movement. 